\title{
Uma visão das relações de poder professor-alunos através de um artefato de acompanhamento automático para sessões de bate-papos em Ambiente Virtual de Aprendizado
}

\author{
Ricardo Domingos Rodriguez', Mariano Pimentel ${ }^{2}$
}

\author{
Centro de Ciencias Exatas e Tecnologia \\ Universidade Federal do Rio de Janeiro (UNIRIO) \\ Av Pasteur 458-22.290-240 - Rio de Janeiro - RJ - Brazil
}

\begin{abstract}
Resumo. Este artigo trata de uma perspectiva das relações de poder em uma sala de aula virtual, onde um artefato tecnológico, criado para auxiliar o professor a identificar os alunos que não participam de uma aula de bate-papo (chat), em um Ambiente Virtual de Aprendizado, pode ser usado como empoderamento e onisciência para o professor e, ao mesmo tempo, como um instrumento de vigilância e punição para os alunos.
\end{abstract}

Abstract. This paper describes from a power relations perspective in a virtual classroom, where an artifact, created to help the teacher identify which students who do not participate in a chat, in a Virtual Environment Learning, can be used as teacher's empowerment and omniscience and, at same time, as an instrument of vigilance and punishment for student.

\section{Motivação}

Em uma sala de aula presencial há alunos que participam, envolvendo-se na retórica do professor, e outros não. Os que participam procuram completar seus pensamentos através de citações, a fim de entender o tema proposto, outros, ainda, propõem questões expondo suas dúvidas, porém, há aqueles que não participam, por acreditar ser o assunto enfadonho, não se interessam, ou, ainda, procrastinam. Em todos os casos, o professor presencial é capaz, a medida que o tempo passa, de identificar cada um desses alunos. Em um AVA baseado em chat há algumas diferenças: O número de mensagens é incessante e não há como o professor identificar quem está participando ou não. O que pode ser visto na aula presencial é capaz de ser imperceptível no AVA. Como o professor pode identificar os alunos que participam "adequadamente" de sua aula? A partir dessa percepção é que realizei essa pesquisa com o grupo Comunicatec (Pimentel, 2006), além de contribuir com o entendimento do que seja o "poder" através de vigilância e punição em um AVA.

\section{Questões de pesquisa}

Para entender as relações de poder em um AVA nessa pesquisa, foi desenvolvido um artefato computacional que poderia auxiliar o professor em seu trabalho. Para tal, partimos do princípio que o artefato daria ao professor a onisciência. Ele receberia mensagens que lhe informariam que alunos estariam participando ou não da aula virtual. Por outro lado, os alunos receberiam, através do mesmo artefato, mensagens automáticas,

ricardo.rodriguez@uniriotec.br spimentel@uniriotec.br 
convidando-os e incentivando-os a participar da conversa. Este contexto nos levou as seguintes questões de pesquisa: (1) O professor e/ou os alunos serão "empoderados" ou o artefato estará os descapacitando? (2) O que os alunos e o professor acham de um acompanhamento automático de suas participações em um AVA? (3) Como definir o que seria uma "participação adequada" nas perspectivas do professor e dos alunos? (4) Finalmente, o artefato desenvolvido será visto como um elemento colaborador ou um instrumento de vigilância e controle do AVA?

\section{Metodologia aplicada e Análise dos resultados}

Nessa pesquisa foi utilizada a epistemologia-metodologia Design Science Research (DSR) (Weringa, 2014) cujo cerne de pesquisa é o conhecimento através da ciência do design ou ciência do artefato, desenvolvido a partir da epistemologia da Ciência do Artificial (Simon, 1996). Como metodologia de análise da percepção do artefato, utilizamos o grupo focal formados pelo professor Pimentel, alunos de mestrado da Unirio e por mim. Assim, analisando o que foi discutido no grupo focal, tivemos como resposta: (1) o artefato permitiu ao professor ter total conhecimento das ações dos alunos, dandolhe uma forma de poder disciplinar exercida verticalmente, que pode ser definida como poder pastoral (Foucault, 1999); (2) para o professor, o controle deveria passar para o artefato, a onisciência o levou a um estado de afastamento da aula. Por outro lado, os alunos eram induzidos a dizer alguma coisa, mesmo que suas opiniões ou comentários não tivessem relação alguma com o tema discutido. Na perspectiva do "sujeito foucaultiano" (Sampaio, 2011): o acompanhamento automático de bate-papo "punia" os alunos que deixavam de enviar mensagens, sem que eles percebessem; (3) o artefato incitou os alunos a participarem constantemente da conversa, pelos constantes avisos convidando-os para a aula; (4) apesar das mensagens demonstrarem um caráter positivo, o artefato agiu como um instrumento de vigilância e punição (Foucault, 1999) para os alunos. O artefato, também, mostrou-se eficaz quanto ao seu propósito, mas não foi eficiente para auxiliar o professor ao dar-lhe a onisciência sobre a inatividade de seus alunos. Em resumo, vimos que o professor sentiu-se sobrecarregado de mensagens, enquanto os alunos não se incomodaram com os avisos recebidos; o artefato mostrou-se "inconveniente" para o professor, na forma pela qual enviou as mensagens, porém, por outro lado, os alunos sugeriram alterações e melhorias no comportamento do artefato, com o objetivo de torná-lo mais controlador, pois o artefato, por diversas vezes, incitou os alunos a participarem da aula, apesar de ser um castigo.

\section{Referencias.}

Foucault, M., 1999. Vigiar e Punir: nascimento da prisão, 20th ed. Vozes, Petrópolis, RJ.

Pimentel, M., 2006. ComunicaTEC: Tecnologias de Comunicação para Educação e

Colaboração. Presented at the III Simpósio Brasileiro de Sistemas de

Informação, SBSI, Curitiba, Paraná.

Sampaio, S.S., 2011. A liberdade como condição das relações de poder em Michel

Foucault.

Simon, H., 1996. The Sciences of the Artificial. MIT Press, Cambridge, MA.

Weringa, R.J., 2014. Design Science Methodology for Information Systems and

Software Engineering. Spring, London. 